\title{
Accumulation of $\alpha$-Synuclein Triggered by Presynaptic Dysfunction
}

\author{
Yasuto Nakata, ${ }^{1,4}$ Toru Yasuda, ${ }^{1,4,5}$ Masahiro Fukaya, ${ }^{2}$ Saori Yamamori, ${ }^{3}$ Makoto Itakura, ${ }^{3}$ Tomoko Nihira, ${ }^{1,4}$ \\ Hideki Hayakawa, ${ }^{1,4}$ Aya Kawanami, ${ }^{1}$ Masakazu Kataoka, ${ }^{6}$ Makiko Nagai, ${ }^{1}$ Hiroyuki Sakagami, ${ }^{2}$ Masami Takahashi, ${ }^{3}$ \\ Yoshikuni Mizuno, ${ }^{4}$ and Hideki Mochizuki ${ }^{1,4,5}$ \\ Departments of ${ }^{1}$ Neurology, ${ }^{2}$ Anatomy, and ${ }^{3}$ Biochemistry, and ${ }^{4}$ Division of Neuroregenerative Medicine, Kitasato University School of Medicine, \\ Sagamihara, Kanagawa 252-0374, Japan, ${ }^{5}$ Department of Neurology, Osaka University Graduate School of Medicine, Suita, Osaka 565-0871, Japan, and \\ ${ }^{6}$ Department of Environmental Science and Technology, Faculty of Engineering, Shinshu University, Nagano-shi, Nagano 380-8553, Japan
}

Pathological examination of dementia with Lewy bodies patients identified the presence of abnormal $\alpha$-synuclein ( $\alpha$ Syn) aggregates in the presynaptic terminals. $\alpha$ Syn is involved in the regulation of soluble $N$-ethylmaleimide-sensitive factor attachment protein receptor (SNARE) complex. Importantly, $\alpha$ Syn-transgenic mouse and postmortem examination of patients with Parkinson's disease have demonstrated the abnormal distribution of SNARE protein in presynaptic terminals. In this study, we investigated the effects of SNARE dysfunction on endogenous $\alpha$ Syn using Snap $25^{\text {S187A/S187A }}$ mutant mice. These mice have homozygous knock-in gene encoding unphosphorylatable S187A-substituted synaptosomal-associated protein of $25 \mathrm{kDa}$ (SNAP-25). The mice displayed a significant age-dependent change in the distribution of $\alpha$ Syn and its Ser ${ }^{129}$-phosphorylated form in abnormally hypertrophied glutamatergic nerve terminals in the striatum. Electron-microscopic analysis revealed the abnormally condensed synaptic vesicles with concomitant mislocalization of $\alpha$ Syn protein to the periactive zone in the glutamatergic nerve terminals. However, the Snap $25^{S 187 A / S 187 A}$ mutant mouse harbored no abnormalities in the nigrostriatal dopaminergic neurons. Our present results suggest that SNARE dysfunction is the initial trigger of mislocalization and accumulation of $\alpha$ Syn, and probably is an important pathomechanism of $\alpha$-synucleinopathies.

\section{Introduction}

$\alpha$-Synucleinopathies are a subgroup of neurodegenerative diseases including dementia with Lewy bodies (DLB), multiple system atrophy (MSA), and Parkinson's disease (PD). The pathological hallmark of the disorders is the formation of intracellular aggregates composed mainly of $\alpha$-synuclein ( $\alpha$ Syn), which are called Lewy bodies and Lewy neurites (Spillantini and Goedert, 2000; Galvin et al., 2001; Yasuda et al., 2012). It was reported recently that $>90 \%$ of $\alpha$ Syn aggregates are present in presynaptic terminals in the form of very small deposits of the affected neurons in DLB (Neumann et al., 2002; Kramer and Schulz-Schaeffer, 2007; SchulzSchaeffer, 2010). However, the mechanisms responsible for presynaptic accumulation of abnormal $\alpha$ Syn remain elusive.

\footnotetext{
Received May 8, 2012; revised Aug. 28, 2012; accepted Oct. 5, 2012.

Author contributions: Y.N., T.Y., and H.M. designed research; Y.N., T.Y., M.F., S.Y., M.I., T.N., H.H., and A.K. performed research; Y.N., T.Y., M.F., S.Y., M.I., T.N., H.H., A.K., M.K., M.N., H.S., M.T., Y.M., and H.M. analyzed data; Y.N. and T.Y. wrote the paper.

This work was supported by Grants from the Japan Science and Technology Agency, Core Research for Evolutional Science and Technology (H.M.); Grants-in-Aid from the Research Committee of CNS Degenerative Diseases, the Ministry of Health, Labour and Welfare of Japan (H.M.); Grant-in-Aid for Research on Applying Health Technology (H23- 015) from the Ministry of Health, Labour and Welfare of Japan (H.M.); Ministry of Education, Culture, Sports, Science and Technology of Japan Grant S0801035 (H.M.); and Grant-in-Aid for Scientific Research on Innovative Areas (Brain Environment) from the Ministry of Education, Science, Sports and Culture of Japan (H.M.).

The authors declare no competing financial interests.

Correspondence should be addressed to Prof. Hideki Mochizuki, Department of Neurology, Osaka University Graduate School of Medicine, 2-2 Yamadaoka, Suita, Osaka 565-0871, Japan. E-mail: hmochizuki@ neurol.med.osaka-u.ac.jp.

DOI:10.1523/JNEUROSCI.2220-12.2012

Copyright $\odot 2012$ the authors $\quad 0270-6474 / 12 / 3217186-11 \$ 15.00 / 0$
}

Generally, $\alpha$ Syn is abundantly localized in the presynaptic nerve terminals (Maroteaux et al., 1988; Iwai et al., 1995). While the physiological functions of $\alpha$ Syn have yet to be defined, several lines of evidence implicated this protein in the modulation of neurotransmitter release through the regulation of formation of the soluble $N$-ethylmaleimide-sensitive factor attachment protein receptor (SNARE) complex (Chandra et al., 2005; Burré et al., 2010; Darios et al., 2010) and the size of synaptic vesicle pool (Murphy et al., 2000; Cabin et al., 2002; Larsen et al., 2006; Nemani et al., 2010). Vesicle-associated membrane protein-2 (VAMP-2) present in the synaptic vesicles, and syntaxin and synaptosomal-associated protein of $25 \mathrm{kDa}$ (SNAP-25) in the presynaptic plasma membrane form the core SNARE complex, which regulate the docking and fusion of synaptic vesicles to the presynaptic membrane (Südhof, 2004). A recent study showed the physical interaction of $\alpha$ Syn with VAMP-2 to promote SNARE assembly (Burré et al., 2010). Cysteine-string protein- $\alpha$ $(\operatorname{CSP} \alpha)$ also participates in SNARE assembly, and mutant mice lacking CSP $\alpha$ displayed impaired SNARE formation and premature death, but both of these phenotypes are counteracted by transgenic expression of $\alpha$ Syn (Chandra et al., 2005; Sharma et al., 2011). However, overexpression of $\alpha$ Syn with no overt toxicity inhibits neurotransmitter release, due to a defective reclustering of synaptic vesicles after endocytosis (Nemani et al., 2010). Additionally, overexpressed $\alpha$ Syn indirectly inhibited SNAREmediated exocytosis by sequestering arachidonic acid, which upregulates syntaxin and enhances its engagement with SNARE complex (Darios et al., 2010). Importantly, abnormal redistribu- 
tion of SNARE proteins has been observed in human PD patients and mice overexpressing a truncated form of human $\alpha$ Syn, which showed decreased release of dopamine (DA) in the striatum (GarciaReitböck et al., 2010). Therefore, presynaptic SNARE dysfunction is considered an initial pathogenic event in $\alpha$-synucleinopathies.

Based on the above background, the present study was designed to investigate the effects of impaired SNARE assembly on the distribution of naive $\alpha$ Syn. We exploited Snap $25^{\text {S187A/S187A }}$ mutant mice. This strain is resistant to the protein kinase C-mediated phosphorylation of SNAP-25 at Ser ${ }^{187}$ and represents a concomitant reduction of neurotransmitter release, including serotonin and DA, from the amygdala, and develops convulsive seizures and anxiety-related behavior in general activity and light-and-dark preference tests (Kataoka et al., 2011). The results indicated that dysfunction of SNARE proteins could trigger abnormal localization and accumulation of presynaptic $\alpha$ Syn, possibly representing one of the pathogenic events in DLB or MSA.

\section{Materials and Methods}

Mice. All experimental protocols described in this study were approved by the Animal Experimentation and Ethics Committee of the Kitasato University School of Medicine. Homozygous SNAP-25 knock-in mutant mice bearing S187A mutation and wild-type littermate control mice were generated based on the procedures described in detail by Kataoka et al. (2011). Briefly, embryonic stem cells with the heterozygous Snap $25^{\text {S187A }}$ mutant allele were generated and microinjected into C57BL/6N blastocysts to obtain heterozygous mutant mice. Male chimeras were bred with C57BL/6N female mice. After the line was backcrossed 13 times, homozygous mice (designated as Snap $25^{\text {S187A/S187A }}$ mice) were obtained by in vitro fertilization. The genotype was checked by PCR. In this experiment, wild-type and Snap $25^{\text {S187A/S187A }}$ mice were used at age 11 (females), 54 (females), 60 (males), and 61 (females) weeks.

Tissue processing. Deeply anesthetized mice (with $250 \mathrm{mg} / \mathrm{kg}$, i.p., sodium pentobarbital) were perfused transcardially with PBS or with $2 \%$ paraformaldehyde/2\% glutaraldehyde in $0.1 \mathrm{~m}$ phosphate buffer (PB). The brains were removed en bloc from the skull and cut sagittally into two brain hemispheres for confocal microscopy, cell counting, electron microscopy, Western blotting, and catecholamine analysis. Tissue processing for conventional electron microscopy is described below (see Conventional electron microscopy). For confocal microscopy and cell counting, hemisphere brain blocks of mice perfused transcardially with PBS or with $2 \%$ paraformaldehyde $/ 2 \%$ glutaraldehyde in $0.1 \mathrm{M} \mathrm{PB}$ were fixed overnight in $4 \%$ paraformaldehyde in PBS and immersed in PBS containing 30\% sucrose until sinking. Coronal sections of the striatum and the entire rostrocaudal extent of the substantia nigra (SN) were cut serially at $20 \mu \mathrm{m}$ thickness using a cryostat (CM1850; Leica Microsystems). For Western blotting and catecholamine measurement by HPLC, brain blocks of mice perfused transcardially with PBS were dissected using the method described previously by our group, to yield the striatal tissues and ventral parts of midbrain tissues including the SN (Yasuda et al., 2011). After completing the dissection, the sections were immediately frozen on dry ice and stored at $-80^{\circ} \mathrm{C}$ until analysis.

Antibodies. The primary antibodies used for confocal microscopy were mouse anti- $\alpha$ Syn (clone 42; diluted at 1:100; BD Biosciences) (TapiaGonzález et al., 2011), rabbit anti- $\alpha$ Syn (1:500; Millipore Bioscience Research Reagents) (Chung et al., 2003; Herzig et al., 2011), rabbit antityrosine hydroxylase (TH) (1:5000; Calbiochem) (Yasuda et al., 2011), mouse anti-synaptophysin (clone SY38; 1:500; Millipore) (Masliah et al., 2001; Tabuchi et al., 2007; Gimbel et al., 2010), rat anti-dopamine transporter (DAT) (clone MAB369; 1:500; Millipore) (Herzig et al., 2011; Kaushal et al., 2011), rabbit or goat anti-vesicular glutamate transporter-1 (VGLUT1) (1:300; Frontier Institute) (Miyazaki et al., 2003; Kawamura et al., 2006), goat anti-VGLUT2 (1:300; Frontier Institute) (Miyazaki et al., 2003; Kawamura et al., 2006), and rabbit antiSer ${ }^{129}$-phosphorylated $\alpha$ Syn (ab59264; 1:100; Abcam) (Pan-Montojo et al., 2010; Yasuda et al., 2011). For Western blotting, primary antibodies used were mouse anti- $\alpha$ Syn (clone 42; 1:150; BD Biosciences), rabbit anti-Ser ${ }^{129}$-phosphorylated $\alpha$ Syn (ab59264; 1:500; Abcam), rabbit antiSNAP25ct (1:1000) (Yamamori et al., 2011), mouse anti-syntaxin 1 (10H5) $(1.4 \mu \mathrm{g} / \mathrm{ml})$ (Yamamori et al., 2011), rabbit anti-VAMP-2 (1.4 $\mu \mathrm{g} / \mathrm{ml}$ ) (Kataoka et al., 2011), mouse anti-synaptophysin (clone SY38; 1:500; Millipore), rabbit anti-TH (1:500; Calbiochem), and rabbit anti$\beta$-tubulin (1:500; Abcam). For immunoelectron microscopy, the primary antibodies used were mouse anti- $\alpha$ Syn (clone $42 ; 1 \mu \mathrm{g} / \mathrm{ml}$; BD Biosciences), guinea pig anti-DAT ( $1 \mu \mathrm{g} / \mathrm{ml}$; Frontier Institute), and rabbit anti-VGLUT1 (1 $\mu \mathrm{g} / \mathrm{ml}$; Frontier Institute).

Confocal microscopy. Free-floating sections were washed in PBS medium containing $0.05 \%$ Triton X-100 (PBS-T). As to the sections prepared from mice perfused transcardially with $2 \%$ paraformaldehyde $/ 2 \%$ glutaraldehyde in $0.1 \mathrm{M} \mathrm{PB}$, they were incubated with Liberate Antibody Binding (L.A.B.) solution (Polysciences) followed by washing in PBS medium and then processed in the same way as other sections. The sections were soaked with blocking agents and then incubated with the primary antibody dissolved in dilution reagent at $4^{\circ} \mathrm{C}$ for $48 \mathrm{~h}$. Vector M.O.M. Immunodetection Kit (Vector Laboratories) was used for blocking and antibody dilution according to the instructions provided by the manufacturer. Subsequently, for fluorescent visualization of the antigens, the sections were incubated for $2 \mathrm{~h}$ in fresh medium containing fluorescein isothiocyanate-conjugated anti-mouse or rabbit IgG, and Cy3-conjugated anti-mouse, rabbit, goat, or rat IgG secondary antibodies (1:200-500; Jackson ImmunoResearch Laboratories). The sections were mounted on slide glass and coverslipped with Vectashield Mounting Medium with or without DAPI (Vector Laboratories). Images were captured using a confocal laser-scanning microscope (model LSM510; Zeiss) equipped with ZEN 2009 software (Zeiss) with identical settings. The software was used for image processing (brightness and contrast adjustment) applied equally to the images of wild-type and mutant mice.

Conventional electron microscopy. For conventional electron microscopy, the hemisphere brains prepared from mice perfused transcardially with $2 \%$ paraformaldehyde $/ 2 \%$ glutaraldehyde in $0.1 \mathrm{M} \mathrm{PB}$ were postfixed in $2 \% \mathrm{OsO}_{4}$ for $1 \mathrm{~h}$. After washing in water, the samples were incubated in $2 \%$ uranyl acetate for $30 \mathrm{~min}$. After dehydration using 50 , 70,90 , and $100 \%$ ethanol solutions and $100 \%$ propylene oxide, the samples were embedded in Epon 812 resin (Nissin EM). Ultrathin sections were obtained using a Leica Ultracut UCT and stained with $2 \%$ uranyl acetate and lead citrate. Electron micrographs were taken with an H-7650 electron microscope (Hitachi).

Immunoelectron microscopy. For preembedding immunoelectron microscopy, parasagittal brain sections ( $60 \mu \mathrm{m}$ in thickness) were incubated successively with $5 \%$ normal goat serum, primary antibodies, and peroxidase- or coloidal gold (1.4 nm)-conjugated secondary antibodies ( $\mathrm{In}$ vitrogen). Immunoreaction was visualized with 3,3'-diaminobenzidine or silver enhancement kit (HQ silver; Nanoprobes). When combining the two methods for double immunoelectron microscopy, the brain tissue was subjected first to immunoperoxidase and then to silver-enhanced immunogold. Sections labeled by immunoperoxidase and silver-enhanced immunogold were subjected to electron microscopy as described above. The size of the nerve terminal was quantitated by using the ImageJ 1.43 software (Wayne Rasband, NIH, Bethesda, MD; http://rsb.info.nih.gov/ij).

Western blotting. Frozen striatal and ventral midbrain tissues were sonicated in chilled CelLytic-MT mammalian tissue lysis/extraction reagent (Sigma-Aldrich) mixed with protease inhibitor mixture set I (Calbiochem) and phosphatase inhibitor mixture set $\mathrm{V}$ (Calbiochem). The samples were centrifuged $\left(20,000 \times g\right.$ for $10 \mathrm{~min}$ at $\left.4^{\circ} \mathrm{C}\right)$, and the resulting supernatants were collected and used for Western blotting. The protein concentration in the lysate of all samples was determined using BCA protein assay kit (Pierce). Each protein sample (5-15 $\mu \mathrm{g})$ was resolved by SDS-PAGE by means of Compact-PAGE-twin (ATTO) and then electrotransferred to Clear Blot Membrane-P (ATTO) using powered BLOTmini (ATTO). The membrane was washed in PBS-T, incubated for $1 \mathrm{~h}$ in PBS-T containing 50\% ChemiBLOCKER (Millipore), and then incubated for $24 \mathrm{~h}$ with the primary antibody in the same fresh medium. Subsequently, the membrane was incubated for $2 \mathrm{~h}$ in fresh medium containing horseradish peroxidase-linked anti-mouse or rabbit IgG secondary antibody (1:10,000-20,000; GE Healthcare), followed by devel- 
opment of chemiluminescence using GE Healthcare ECL Plus Western Blotting Detection System (GE Healthcare). The image was captured using LAS-4000 (Fujifilm), and the signal intensity was quantitated using the ImageJ 1.43 software.

Assay for SNARE complex assembly. SNARE complex assembly was assessed by measuring the levels of the high-molecular-weight SDSresistant complex in Western blotting performed without boiling of the samples before gel electrophoresis (Hu et al., 2002; Asuni et al., 2008; Sakisaka et al., 2008). Striatal lysate samples (15 $\mu$ g of protein/sample) of wild-type and Snap $25^{\text {S187A/S187A }}$ mice were resolved in the SDS sample buffer. Samples were incubated for $20 \mathrm{~min}$ at room temperature and were further incubated at room temperature or boiled at $100^{\circ} \mathrm{C}$ for $3 \mathrm{~min}$. Subsequently, they were analyzed by SDS-PAGE followed by the immunoblotting using the rabbit anti-SNAP25ct primary antibody (1:1000) (Yamamori et al., 2011) and horseradish peroxidase-linked anti-rabbit IgG secondary antibody (1:10,000; GE Healthcare). Except for the sample preparation before gel electrophoresis, all procedures were the same as described above (see Western blotting).

Determination of striatal levels of DA and its metabolites by HPLC. Frozen striatal tissues were sonicated in $50 \mathrm{~mm}$ sodium acetate. The samples were centrifuged $\left(20,000 \times g\right.$ for $10 \mathrm{~min}$ at $\left.4^{\circ} \mathrm{C}\right)$, and the resulting supernatants were mixed with equal volumes of $0.2 \mathrm{~N}$ perchloric acid. The samples were centrifuged $\left(20,000 \times g\right.$ for $10 \mathrm{~min}$ at $\left.4^{\circ} \mathrm{C}\right)$, and the resulting supernatants were subjected to measurement of DA, homovanillic acid (HVA), and 2-(3,4-dihydroxyphenyl)-acetic acid (DOPAC) concentrations by HPLC, using an HPLC system equipped with electrochemical detection (ECD-100; EICOM; applied voltage, 500 $\mathrm{mV}$ ) and reverse-phase column (TSK gel ODS-80TM; Tosoh). The HPLC system consisted of a pump (PU-980; Jasco; flow rate, $1.0 \mathrm{ml} /$ min), autosampler (AS-1550; Jasco), column oven (860-CO; Jasco), and degasser (DG-2080-53 Jasco). The mobile phase consisted of a solution, $\mathrm{pH} 3.72$, containing the following: $0.085 \mathrm{M} \mathrm{NaH} \mathrm{PO}_{4} \cdot 2 \mathrm{H}_{2} \mathrm{O}, 2.5 \mathrm{~mm}$ 1-octanesulfonic acid sodium salt, $20 \mu \mathrm{M}$ EDTA-2Na, and 15\% methanol. The concentrations of DA, HVA, and DOPAC were determined in nanomoles per gram of tissue weight, and the results were expressed relative to the values of wild-type mice.

Cell count. For DA cell counting in the SN pars compacta (SNpc), every fourth $20-\mu \mathrm{m}$-thick serial section of the brain was immunostained for $\mathrm{TH}$ and counterstained with cresyl violet (Nissl staining) (Furuya et al., 2004; Yasuda et al., 2011). The numbers of TH- and Nissl-doublepositive cells in the $\mathrm{SNpc}$ were counted both in wild-type and Snap $25^{\text {S187A/S187A }}$ mice in a blind manner. The SNpc cells that have nuclei optimally visible by TH immunostaining, and nuclei, cytoplasm, and nucleoli prominently stained by Nissl staining were counted. To avoid double counting of neurons with unusual shapes, TH- and Nissl-doublepositive cells were counted only when their nuclei and nucleoli were optimally visualized. The rostral end of the SNpc was determined to the level where TH- and Nissl-double-positive cells began to appear $(\sim 2.60$ mm caudal to the level of the bregma) (Franklin and Paxinos, 2008), and the caudal end of the SNpc was defined to the level where TH- and Nissl-double-positive cells and oculomotor nerves can be observed ( $\sim 3.80 \mathrm{~mm}$ caudal to the level of the bregma) (Yasuda et al., 2011). In the rostral half region of the $\mathrm{SN}(\sim 2.60-3.16 \mathrm{~mm}$ caudal to the level of the bregma), the SNpc was distinguished from medial ventral tegmental area (VTA) by the vertical line extended from the medial end of the cerebral peduncle. In the caudal region of the $\mathrm{SN}$ where the medial lemniscus can be observed ( $\sim 3.16-3.80$ caudal to the level of the bregma), the SNpc and medial VTA were divided along the medial lemniscus.

Statistical analysis. All data are expressed as mean \pm SEM, excluding those of VGLUT1-positive nerve area, which are expressed as mean \pm $\mathrm{SD}$. The two-tailed Student's $t$ test (for two groups) was applied. A value of $p<0.05$ denoted the presence of statistically significant difference.

\section{Results}

Abnormal distribution of $\alpha$ Syn protein at presynaptic terminals in the striatum of Snap $25^{\text {S187A/S187A }}$ mice

Using immunohistochemistry, we investigated the distribution of endogenous $\alpha$ Syn in the striatum of Snap $25^{\text {S187A/S187A }}$ mice, which have unphosphorylatable Ala at position $\mathrm{Ser}^{187}$ in the SNAP-25 protein. A significant decrease of neurotransmitter release was noted in serotonergic and dopaminergic systems in the amygdala, which was associated with behavioral abnormalities, including spontaneous convulsive seizures (Kataoka et al., 2011). Confocal microscopic analysis of the striatal sections of the Snap $25^{\text {S187A/S187A }}$ mice showed altered distribution of endogenous $\alpha$ Syn, which resembled coarse granular deposits, at the age of 11 weeks, compared with age-matched wild-type control. These changes were prominent in 60-week-old (54-week-old or more was designated as aged, hereafter) Snap $25^{\text {S187A/S187A }}$ mice (Fig. 1A,B), indicating an age-dependent progressive manner of redistribution.

Next, we examined the localization of $\alpha$ Syn in the presynaptic terminals by using anti-synaptophysin antibody. Aged Snap25 $5^{\text {S187A/S187A }}$ mice showed similar alternation of the immunoreactivity for synaptophysin as observed for $\alpha$ Syn, compared with the wild-type (Fig. $1 C, D$ ). Moreover, $\alpha$ Syn-immunopositive granular structures were largely overlapped with synaptophysin. These results indicate that $\alpha$ Syn accumulates mainly in the presynaptic terminals in the striatum. We also analyzed the immunostaining pattern for $\operatorname{Ser}^{129}$-phosphorylated $\alpha$ Syn (p- $\alpha$ Syn), which was found specifically in human $\alpha$-synucleinopathies (Fujiwara et al., 2002). Majority of $\alpha$ Syn-positive granular deposits were immunopositive for $\mathrm{p}-\alpha \mathrm{Syn}$, which were detected at negligible amounts in wild-type control mice (Fig. $1 F, G$ ). These results indicate that the abnormal accumulation of $\alpha$ Syn in the striatum of Snap $25^{\text {S187A/S187A }}$ mice represents in part the pathological changes in human DLB brains.

\section{Abnormal accumulation of $\alpha$ Syn and p- $\alpha$ Syn proteins in the striatum of Snap $25^{\text {S187A/S187A }}$ mice}

Next, we measured $\alpha$ Syn and $\mathrm{p}-\alpha$ Syn protein levels in the striatal tissues of aged Snap $25^{\text {S187A/S187A }}$ mice. A significant decrease of SNAP-25 protein was found in Snap $25^{\text {S187A/S187A }}$ mice $(p<$ 0.0001 ) compared with age-matched wild-type mice, confirming our previous findings (Kataoka et al., 2011). Importantly, $\alpha$ Syn $(\sim 1.5$-fold; $p=0.0047)$ and $\mathrm{p}-\alpha$ Syn $(\sim 1.7$-fold; $p=0.0080)$ protein levels were higher than age-matched wild-type mice (Fig. $2 A, B)$. These results indicate that the abnormal distribution of $\alpha$ Syn and p- $\alpha$ Syn in the presynaptic terminals (Fig. $1 F$ ) was reflected by increased amount of these proteins. In addition, high levels of VAMP-2 $(\sim 1.3$-fold; $p=0.0011)$, but neither syntaxin nor synaptophysin, were found in the striatum of aged Snap $25^{\text {S187A/S187A }}$ mice (Fig. 2A,B), compared with whole-brain lysate prepared from young Snap $25^{\text {S187A/S187A }}$ mice (Kataoka et al., 2011).

\section{Ultrastructural analysis of $\alpha$ Syn distribution in presynaptic terminals}

To investigate in detail the morphological changes in the presynaptic terminals, we used electron microscopy to analyze the striatum of the aged mice. In Snap $25^{\text {S187A/S187A }}$ mice, condensed synaptic vesicles were abundantly present in large excitatory nerve terminals, compared with the normal uniform distribution of the vesicles in wild-type mice (Fig. $3 A, B$ ). These results suggest possible decrease of presynaptic neurotransmitter release in Snap $25^{\text {S187A/S187A }}$ mice. Subsequent immunoelectron-microscopic examination of $\alpha$ Syn in the synapses showed predominant localization of $\alpha$ Syn proteins in the periactive zone of enlarged excitatory presynaptic nerve terminals in the aged Snap $25^{\text {S187A/S187A }}$ mice, compared with the wild type (Fig. $3 C, D$ ). 

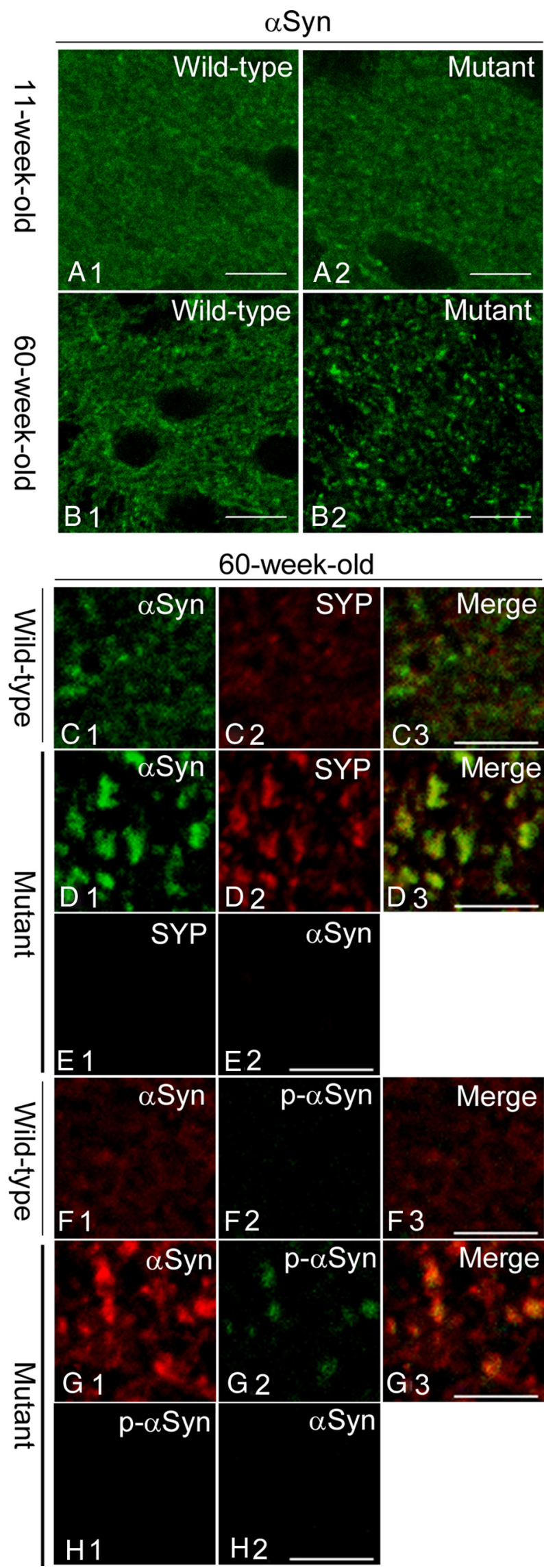

Figure 1. Altered localization of $\alpha$ Syn and its accumulation in presynaptic terminals in the striatum of Snap $25^{\text {S187A/S187A }}$ mice. $\boldsymbol{A}, \boldsymbol{B}$, Striatal sections of wild-type and Snap $25^{\text {S187A/S187A }}$
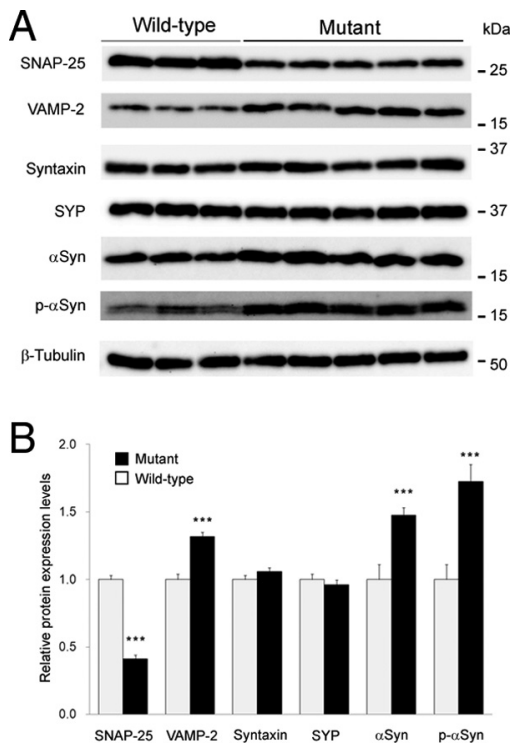

Figure 2. Increase in endogenous $\alpha$ Syn and $\mathrm{p}-\alpha$ Syn in the striatum of Snap25 $5^{\text {S187A/5187A }}$ mice. $\boldsymbol{A}, \boldsymbol{B}$, Western blotting was performed for synaptic marker proteins using the striatal tissues at postnatal week 61. $\boldsymbol{A}$, Representative Western blotting images of two to five independent experiments, each involving three and five mice for wild-type and Snap $25^{\text {5187A/S187A }}$ (mutant), respectively. Mutant mice showed increased band intensity of $\alpha$ Syn, $\mathrm{p}$ - $\alpha$ Syn, and VAMP-2 compared with the wild type, while that of SNAP-25 was decreased. $\boldsymbol{B}$ Relative protein expression levels expressed relative to the loading control ( $\beta$-tubulin). The band intensity was quantitated using the ImageJ 1.43 software and expressed as the relative protein expression level. Significant increases in $\alpha$-Syn, p- $\alpha$ Syn, and VAMP-2, and significant decrease in SNAP-25 were observed in mutant mice. No significant differences were noted in other synaptic protein markers. Data are mean \pm SEM of two to five independent experiments, each involving three and five mice for wild-type and mutant, respectively. ${ }^{* * *} p<0.01$ (two-tailed $t$ test).

Decreased ability of SNARE complex assembly in Snap25 $5^{\text {S187A/S187A }}$ mice

Given that Snap $25^{\text {S187A/S187A }}$ mice clearly displayed the significant decrease in the SNAP-25 protein expression and abnormal distribution of the synaptic vesicle in the presynaptic terminals (Figs. 2, 3B), we evaluated the functional ability to produce the SNARE complex in Snap $25^{\text {S187A/S187A }}$ mice. SNARE complex assembly was assessed by measuring the levels of the highmolecular-weight heat-sensitive SDS-resistant complex in Western blotting. As shown in Figure 4A, compared with boiled sample of the wild type, SNAP-25-immunoreactive bands were shifted to the higher molecular masses $(\sim 75$ to $\sim 250 \mathrm{kDa})$ in unboiled samples of wild-type and Snap $25^{\text {S187A/S187A }}$ mice. However, the relative signal intensity of higher molecular masses normalized by $\beta$-tubulin (loading control) was significantly reduced in Snap25 $5^{S 187 A / S 187 A}$ mice, compared with the wildtype mice $(p=0.00463)$ (Fig. $4 B)$. These observations indi-

(mutant) mice at postnatal weeks 11 and 60 were immunostained for $\alpha$ Syn ( $n=3$ for each genotype). Compared with the wild-type mice $\left(\boldsymbol{A}_{1}, \boldsymbol{B}_{1}\right), \alpha$ Syn was localized and formed coarse granular deposits in mutant mice at postnatal weeks 11 and $60\left(A_{2}, B_{2}\right)$. The severity of the change was more prominent at postnatal week 60 . Scale bars, $10 \mu \mathrm{m}$. $\mathbf{C}-\boldsymbol{H}$, Sections were coimmunostained for $\alpha$ Syn, and synaptophysin (SYP) or $\mathrm{p}-\alpha$ Syn. Confocal images showed altered localization of $\operatorname{SYP}\left(\boldsymbol{D}_{2}\right)$ and $p-\alpha \operatorname{Syn}\left(\boldsymbol{G}_{2}\right)$ and colocalization with $\alpha$ Syn-positive coarse granular deposits $\left(D_{1}, G_{7}\right)$ in mutant mice $\left(\boldsymbol{D}_{3}, \boldsymbol{G}_{3}\right)$. No cross-reactivity was observed for the sections of the mutant mice exposed to a single primary antibody followed by the treatment of both secondary antibodies were observed $\left(\boldsymbol{E}_{1}, \boldsymbol{E}_{2} ; \boldsymbol{H}_{1}, \boldsymbol{H}_{2}\right)$ [i.e., negligible green $\left(\boldsymbol{E}_{1}\right)$ and red fluorescence $\left(\boldsymbol{E}_{2}\right)$ for the sections treated with anti-SYP and $\alpha$ Syn antibody, respectively]. Scale bars, $5 \mu \mathrm{m}$. 
cated the decreased ability of the SNARE complex assembly in Snap $25^{\text {S187A/S187A }}$ mice compared with the wild-type mice. This is considered to represent the functional deficit possibly attributable to the decreased level of the SNAP-25 and the insensitivity of protein kinase C-mediated phosphorylation at Ser ${ }^{187}$ in Snap25 $2187 A / S 187 A$ mice.

\section{$\alpha$ Syn accumulation and enlargement of} corticostriatal nerve terminals

The striatal spiny interneurons receive excitatory outputs from cortical and thalamic tracts, and these projections use glutamate as the neurotransmitter (Gerfen and Surmeier, 2011). VGLUT1 and VGLUT2 are localized to the excitatory nerve terminals projecting from the cortical and the thalamic area, respectively, in the striatum. Then, we investigated the distribution of $\alpha$ Syn-immunopositive deposits with VGLUT1 or VGLUT2 to verify the abnormal accumulation of $\alpha$ Syn in the corticostriatal or the thalamostriatal neuronal terminals. As shown in Figure $5 B_{2}$, we found similar alternation of the immunoreactivity for VGLUT1 as observed for $\alpha$ Syn in the aged Snap $25^{\text {S187A/S187A }}$ mice compared with wild-type normal ones (Fig. $5 A_{2}$ ). Importantly, such immunoreactivity for VGLUT1, but not for VGLUT2, was exclusively colocalized with $\alpha$ Syn (Fig. $5 B_{3}, E_{3}$ ). We also performed double immunostaining with anti-pSyn and anti-VGLUT1 antibodies and found the VGLUT1-immunopositive structures to be immunopositive for p- $\alpha$ Syn (Fig. $5 G_{3}$ ). These observations suggest accumulation of $\alpha$ Syn and p- $\alpha$ Syn mainly in the enlarged VGLUT1-positive nerve terminals.

Immunoelectron-microscopic examination showed massive enlargement of the VGLUT1-positive nerve terminals in the aged Snap $25^{\text {S187A/S187A }}$ mice (Fig. 5I,J). Quantitative analysis of the size of the VGLUT1-positive nerve terminals based on the cumulative probability curve confirmed a significantly larger size in Snap $25^{\text {S187A/S187A }}$ mice compared with wild-type mice (Fig. $5 K$ ). The size of the VGLUT1-positive nerve terminals reached a plateau at $0.8 \mu \mathrm{m}^{2}$ in wild-type mice, while that of Snap $25^{S 187 A / S 187 A}$ mice reached a plateau at $3.6 \mu \mathrm{m}^{2}$. The size of $\sim 40 \%$ of the VGLUT1-positive nerve terminals in the mutant mice was larger than the maximum size measured in wild-type mice. Specifically, the size of the VGLUT1-positive nerve terminals in the mutant mice was approximately fourfold larger than the wild type ( $p=$ 0.0030) (Fig. 5L).

\section{No significant changes in nigrostriatal dopaminergic system} Finally, we examined the effect of SNARE dysfunction on the nigrostriatal dopaminergic system, which is affected in parkinsonian brains. The striatal sections of aged Snap $25^{\text {S187A/S187A }}$ mice were co-
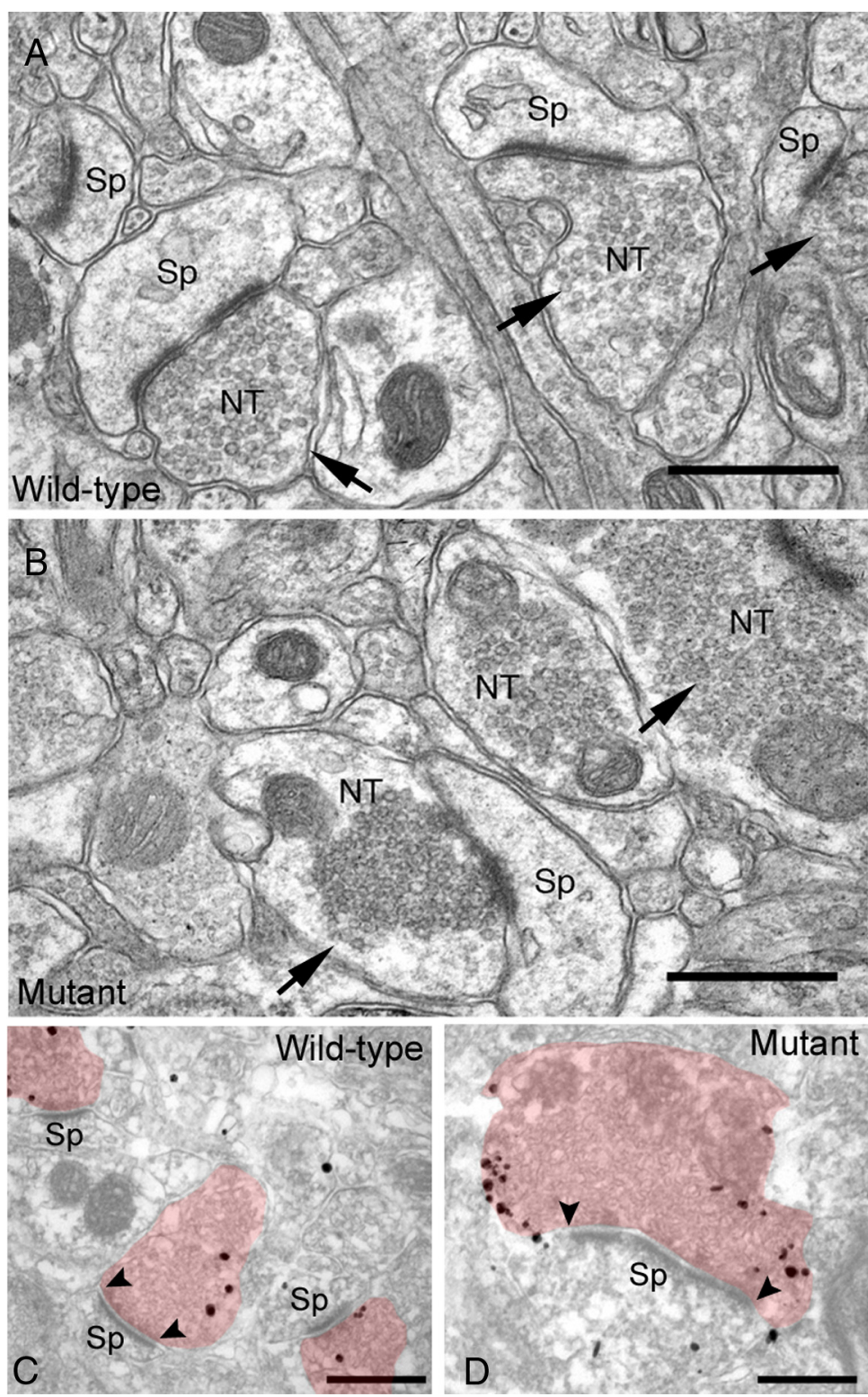

Figure 3. Abnormal excitatory nerve terminals in the striatum of Snap $25^{5187 A / 5187 A}$ (mutant) mice. Representative electron micrographs of wild-type and mutant mice at postnatal week 60 ( $n=3$ for each genotype). Synaptic vesicles were homogeneously distributed in the cytoplasm of the excitatory nerve terminals in wild-type mice $(\boldsymbol{A})$, while they were tightly assembled in mutant mice $(\boldsymbol{B})$. Note the alteration of subcellular localization of $\alpha$-Syn (immunogold particles) and increased number of $\alpha$ Syn nerve terminals in mutant mice $(\boldsymbol{D})$, but not in wild-type mice $(\boldsymbol{C})$. Arrows, excitatory nerve terminals; arrowheads, edges of active zone. NT, Nerve terminal; Sp, dendritic spine. Scale bars, $500 \mathrm{~nm}$.

immunostained for $\alpha$ Syn and dopaminergic neuronal markers (TH or DAT). The $\alpha$ Syn-immunopositive deposits appeared adjacent to, but hardly colocalized with both DAT and TH in Snap25 $5^{\text {S187A/S187A }}$ mice. The distribution patterns of DAT- and TH-immunoreactive deposits in the striatum were not significantly different between wild-type and mutant mice (Fig. $6 A-D$ ). These results imply that the nigrostriatal dopaminergic neurons are not affected in Snap25 $5^{\text {S187A/S187A }}$ mice.

To clarify this point further, we conducted immunoelectronmicroscopic examination of DAT-positive dopaminergic nerve terminals. There were no significant differences in any structural alternations including condensation of synaptic vesicles (Fig. $6 E, F)$. Furthermore, we found no significant differences in the subcellular localization of $\alpha$ Syn protein between the aged wildtype and Snap25 $5^{\text {S187A/S187A }}$ mice (Fig. $6 G, H$ ). 


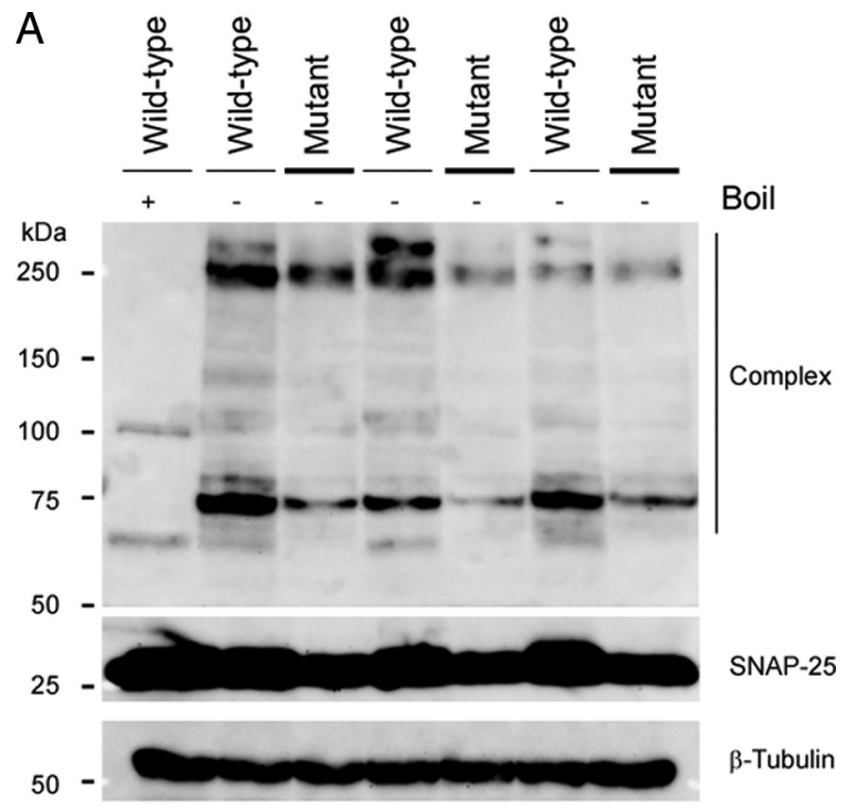

B

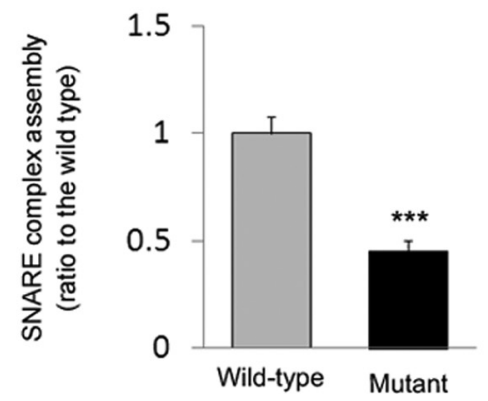

Figure 4. Decreased ability of the SNARE complex assembly in Snap $25^{5187 A / S 187 A}$ (mutant) mice. $\boldsymbol{A}, \boldsymbol{B}$, Western blotting was performed for unboiled or boiled samples of wild-type and mutant mice (at postnatal week 61) before electrophoresis followed by the immunoblotting using SNAP-25ct antibody. $\boldsymbol{A}$, Representative Western blotting image of two to three independent experiments was provided. Heat-sensitive SDS-resistant SNAP-25ct-immunoreactive bands were detected at high molecular mass $(\sim 75$ to $\sim 250 \mathrm{kDa})$ in wild-type and mutant mice, indicating the presence of the SNARE complex. However, band intensity of the mutant mice, especially at $\sim 75 \mathrm{kDa}$, was decreased compared with the wild-type mice. $\boldsymbol{B}$, Relative levels of the SNARE complex assembly relative to the loading control ( $\beta$-tubulin). The band intensity was quantitated using the ImageJ 1.43 software and expressed as the relative protein expression level. Significant decrease in SNARE complex assembly was observed in mutant mice compared with the wild-type mice. Data are mean \pm SEM of two to three independent experiments, each involving three mice for each genotype. ${ }^{* *} p<0.01$ (two-tailed $t$ test).

We also investigated the functional preservation of the nigrostriatal dopaminergic neurons in the aged Snap $25^{\text {S187A/S187A }}$ mice. No significant difference was found in the number of TH- and Nissl-double-positive cells in the SNpc between wild-type and Snap $25^{\text {S187A/S187A }}$ mice (Fig. 6I,J). There were also no significant differences in the levels of TH protein in the midbrain tissue and DA and its metabolites, HVA and DOPAC, in the striatum between the aged wild-type and Snap $25^{\text {S187A/S187A }}$ mice (Fig. $6 \mathrm{~K}-$ $M)$. These results suggest that SNARE dysfunction does not seem to be involved in the initiation of PD-related pathologic changes in nigrostriatal dopaminergic neurons.

\section{Discussion}

In this study, we found that SNARE dysfunction leads to presynaptic accumulation of endogenous $\alpha$ Syn, a process that probably represents the initial pathological event in DLB. Previous studies using neural preparations showed that the neurotransmitter release is regulated by protein kinase $\mathrm{C}$, which phosphorylates
Ser ${ }^{187}$ residue in SNAP-25, augmenting exocytosis of synaptic vesicles (Majewski and Iannazzo, 1998; Morgan et al., 2005). Patch-clamp analysis of chromaffin cells that overexpress the S187A form of SNAP-25 inhibited the rate of refilling of presynaptic vesicle pool (Nagy et al., 2002). Recently, we reported that Snap25 $5^{\text {S187A/S187A }}$ mice show reduced DA and serotonin release in amygdala (Kataoka et al., 2011). In human DLB brains, $>90 \%$ of $\alpha$ Syn aggregates are located in the presynaptic terminals in the form of small deposits (Neumann et al., 2002; Kramer and Schulz-Schaeffer, 2007; Schulz-Schaeffer, 2010). This is consistent with the present findings of abnormal accumulation of $\alpha$ Syn in presynapses, suggesting that this process is the initial pathological event in DLB, eventually leading to the death and degeneration of neuronal cells (Orimo et al., 2008). Another finding that lends support to the role of $\alpha$ Syn aggregates in the presynaptic terminals in DLB was the lack of histopathological changes in the dopaminergic terminals in the present study.

In experiments on glutamate release conducted in hippocampal slices prepared from $\alpha$ Syn knock-out mice (Gureviciene et al., 2007), paired-pulse facilitation was significantly weaker, and high-frequency-induced long-term potentiation and frequency facilitation were not observed. These findings suggest that $\alpha$ Syn contributes to mobilization of glutamate-containing vesicles from the reserve pool (Gureviciene et al., 2007). Thus, $\alpha$ Syn may act as a positive regulator of neurotransmitter release at presynaptic terminals. Therefore, presynaptic accumulation of $\alpha$ Syn observed in Snap $25^{\text {S187A/S187A }}$ mice might reflect a compensatory response to a possible SNARE dysfunction-related chronic shortage of neurotransmitter release in the VGLUT1-positive nerve terminals.

In the striatum, the medium spiny neurons, which constitute $>90 \%$ of all striatal neurons, receive output from glutamatergic axons that contact the spine head and dopaminergic axons that synapse with the dendritic spine neck. DA released from dopaminergic axons regulates the release of glutamate via $\mathrm{D}_{2}$-like receptors on the corticostriatal nerve terminals (Bamford et al., 2004; Wickens and Arbuthnott, 2005). In the present study, we found no significant changes in the striatal tissue levels of DA and its metabolites. These findings confirmed the results reported in our previous study using Snap $25^{\text {S187A/S187A }}$ mice, whereas microdialysis analysis study revealed marked reduction of DA release from the amygdala (not measured in other brain regions) (Kataoka et al., 2011). In addition, in another in vitro study using PC12 cells, phosphorylation of SNAP-25 at S187 potentiated calciumdependent DA release and recruitment of synaptic vesicles containing DA (Shimazaki et al., 1996; Iwasaki et al., 2000; Shoji-Kasai et al., 2002). These observations suggest decreased striatal DA release in Snap $25^{\text {S187A/S187A }}$ mice, resulting in increased demand for neurotransmitter release at glutamatergic nerve terminals. Thus, presynaptic accumulation of $\alpha$ Syn might reflect a possible compensatory response to low DA inhibitory control over cortical glutamatergic drive.

Increased expression of VAMP-2 protein accompanied increased $\alpha$ Syn expression in the striatum of Snap25 $2187 A / S 187 A$ mice. Binding of the $\mathrm{C}$ terminus of $\alpha \mathrm{Syn}$ to the $\mathrm{N}$ terminus of VAMP-2 primes the subsequent SNARE complex assembly (Burgoyne and Morgan, 2011). Therefore, the increased VAMP-2 level might also reflect a compensatory response to the impaired synaptic vesicle release by enhancing SNARE complex formation in concert with the increased $\alpha$ Syn.

Presynaptic neurotransmitter release is mediated by the synaptic vesicle cycle, consisting of exocytosis followed by en- 

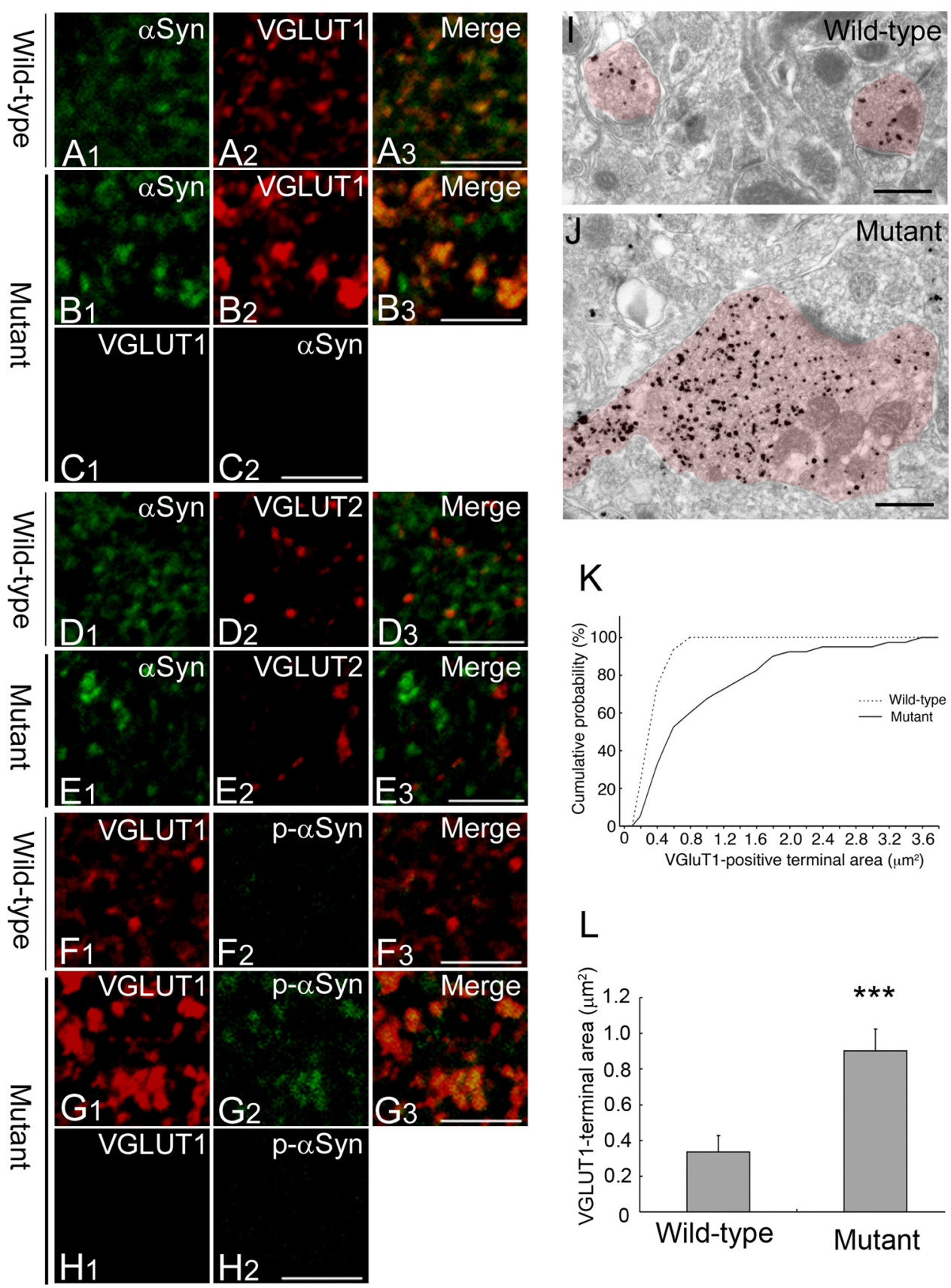

Figure 5. Accumulation of $\alpha$ Syn in the hypertrophied VGLUT1-positive nerve terminals. A-E, Striatal sections of wild-type and Snap25 $5^{5187 A / 5187 A}$ (mutant) mice at postnatal week 60 were coimmunostained for $\alpha$ Syn (green) and VGLUT1 or VGLUT2 (red) ( $n=3$ for each genotype). Confocal images showed altered localization of VGLUT1 with more granular appearance in mutant mice $\left(\boldsymbol{B}_{2}\right)$ compared with wild-type mice $\left(\boldsymbol{A}_{2}\right)$. Immunopositive structures for VGLUT1, but not for VGLUT2, marked colocalization with $\alpha$ Syn-positive granular deposits $\left(\boldsymbol{B}_{3}, \boldsymbol{E}_{3}\right)$. No cross-reactivity was observed for the sections of the mutant mice treated with a single antibody followed by both the secondary antibodies, as evidenced by negligible green $\left(\boldsymbol{C}_{1}\right)$ and red fluorescence $\left(\boldsymbol{C}_{2}\right)$ for the sections treated with anti-VGLUT1 and $\alpha$ Syn antibody, respectively. Scale bars, $5 \mu \mathrm{m}$. $\boldsymbol{F}-\boldsymbol{H}$, Sections were coimmunostained for VGLUT1 (red) and p- $\alpha$ Syn (green) ( $n=3$ for each genotype). Confocal images showed marked colocalization of VGLUT1 and p- $\alpha$ Syn in mutant mice $\left(\boldsymbol{G}_{3}\right)$. Similarly, no cross-reactivity was observed as evidenced by negligible red $\left(\boldsymbol{H}_{\boldsymbol{7}}\right)$ and green fluorescence $\left(\boldsymbol{H}_{\mathbf{2}}\right)$ for the sections treated with anti-VGLUT1 and $\alpha$ Syn antibody, respectively. Scale bars, $5 \mu \mathrm{m}$. I,J, Representative electron micrographs showing VGLUT1-positive nerve terminals (labeled with immunogold particles). Note the hypertrophy of VGLUT1-positive nerve terminals in mutant mice $(\boldsymbol{J})$, but not in wild-type mice $(\boldsymbol{I})$. Scale bars, $500 \mathrm{~nm}$. $\boldsymbol{K}, \boldsymbol{L}$, Q Quantitative analysis of VGLUT1-positive nerve terminal area in three mice per group. The size was measured in 100 nerve terminals per animal. Cumulative probability $(\boldsymbol{K})$ and group mean value $(\boldsymbol{L})$ were calculated and showed a larger nerve terminal area in mutant mice than the wild type. Data are mean \pm SD. ${ }^{* *} p<0.01$ (two-tailed $t$ test).

docytosis and recycling. Exocytosis incorporates synaptic vesicles into the presynaptic terminal membranes and increases the surface area, while endocytosis retrieves the excess plasma membrane components followed by recycling to form other synaptic vesicles. Under normal conditions, the dynamics of the balance between exocytosis and endocytosis is well preserved to maintain the correct surface area of the presynaptic terminal (Hayes and Baines, 1996; Haucke et al., 2011). However, excessive accumulation of presynaptic vesicles and enlargement of the VGLT1-positive nerve terminals was observed in Snap $25^{\text {S187A/S187A }}$ mice. Taking into consideration the synaptic vesicle cycle, our findings suggest that the balance of the cycle was biased toward decreased exocytosis concomitant with possible decreased endocytosis. 

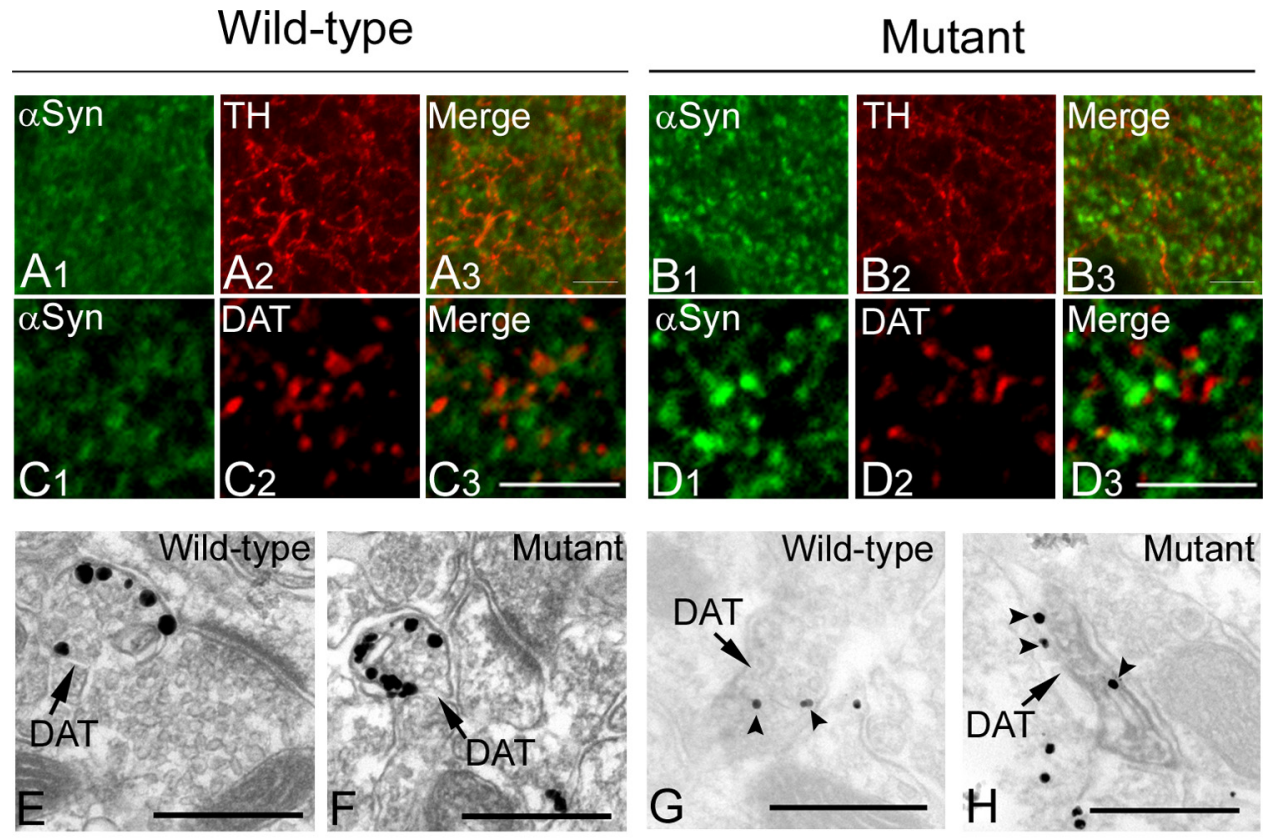
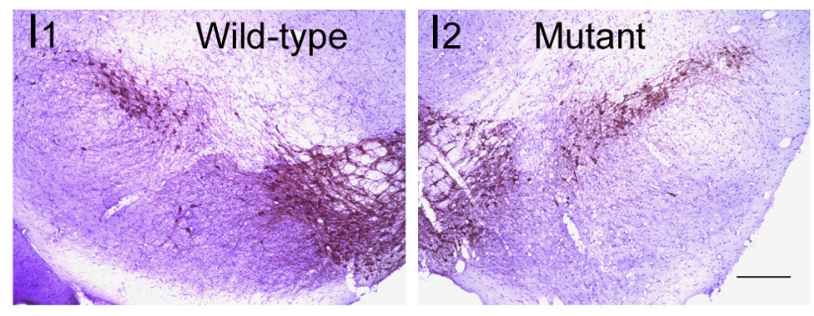

$\mathrm{K}$

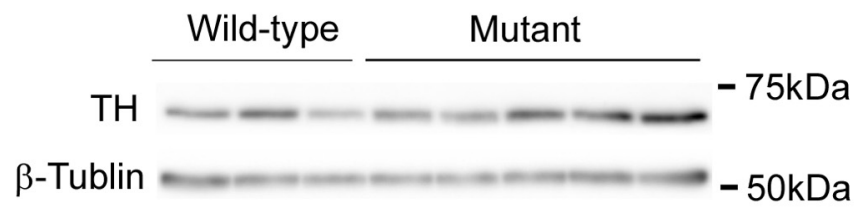

$\mathrm{M}$

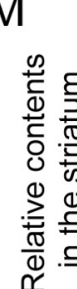

1.5

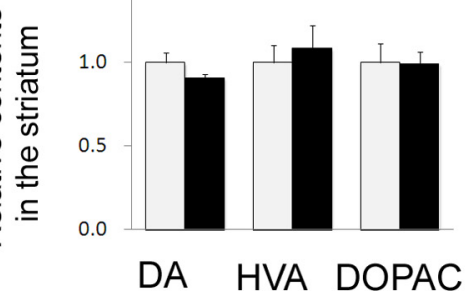

$\mathrm{J}$
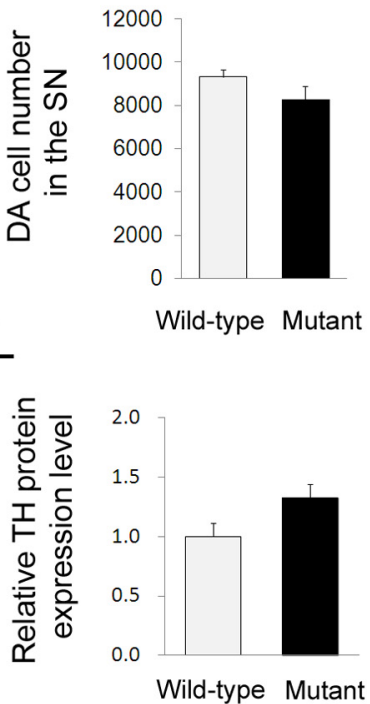

Figure 6. Lack of neurodegenerative changes in nigrostriatal dopaminergic neurons. A-D, Striatal sections of wild-type and Snap25 $5^{5187 A / 5187 A}$ (mutant) mice at postnatal week 60 were coimmunostained for $\alpha$-Syn (green) and TH or DAT (red) $\left(n=3\right.$ for each genotype). There were no significant differences in the distribution pattern of TH $\left(\boldsymbol{A}_{2}, \boldsymbol{B}_{2}\right)$ and DAT $\left(\boldsymbol{C}_{2}, \boldsymbol{D}_{2}\right)$ between wild-type and mutant mice. $\alpha$ Syn-positive granular deposits $\left(\boldsymbol{B}_{1}, \boldsymbol{D}_{1}\right)$ were rarely colocalized with TH or DAT $\left(\boldsymbol{B}_{\boldsymbol{B}}, \boldsymbol{D}_{3}\right)$. Scale bars, $5 \mu \mathrm{m}$. $\boldsymbol{E}-\boldsymbol{H}$, Representative electron micrographs of dopaminergic nerve terminals at postnatal week $60(n=3$ for each genotype). They were identified by silver particles $(\boldsymbol{E}, \boldsymbol{F})$ or DAB labeling $(\boldsymbol{G}, \boldsymbol{H})$ for DAT (arrows). There were no significant differences in subcellular localization of synaptic vesicles $(\boldsymbol{E}, \boldsymbol{F})$ or $\alpha$ Syn (arrowheads, silver particles) $(\boldsymbol{G}, \boldsymbol{H})$ between wild-type and mutant mice. Scale bars, $500 \mathrm{~nm}$. $I, J$, Representative micrographs of the substantia nigra of wild-type and mutant mice at postnatal week 60 immunostained for TH and counterstained with cresyl violet. Scale bars: $I_{1}$, $I_{2}, 200 \mu \mathrm{m}$. Number of DA cell bodies counted in three mice of each genotype. Data are mean \pm SEM $(\boldsymbol{J})$. $\boldsymbol{K}, \boldsymbol{L}$, Western blotting was performed using substantia nigral tissues at postnatal week 61. Representative images of Western blotting from two independent experiments, each involving three and five mice of wild-type and mutant mice, respectively ( $\boldsymbol{K}$ ). Relative $T H$ protein expression levels (relative to the expression of $\beta$-tubulin) were expressed relative to the value of wild-type mice $(\boldsymbol{L})$. Data are mean \pm SEM of two independent experiments, each involving three and five mice of wild-type and mutant, respectively. $M$, Quantification of DA, HVA, and DOPAC levels in the striatum of mice at postnatal week 54 . Data were expressed relative to those of wild-type mice and represent the mean \pm SEM of duplicate measurement of one experiment involving four mice of each genotype. There were no significant differences between wild-type and mutant mice $(\boldsymbol{J}, \boldsymbol{L}, \boldsymbol{M})$ (two-tailed $t$ test). 
The enlarged VGLUT1-positive nerve terminals of Snap $25^{\text {S187A/S187A }}$ mice showed concomitant accumulation of $\alpha$ Syn and p- $\alpha$ Syn. Kramer and Schulz-Schaeffer (2007) have previously reported that $90 \%$ or even more of $\alpha$ Syn aggregates in DLB cases were located at the presynapses in the form of very small deposits. In parallel, dendritic spines were retracted, whereas the presynapses were relatively preserved, suggesting that a neurotransmitter deprivation may explain the cognitive impairment in DLB (Kramer and Schulz-Schaeffer, 2007; Schulz-Schaeffer, 2010). While the presynaptic aggregates did not contain much $\mathrm{p}-\alpha$ Syn in their examination (Kramer and Schulz-Schaeffer, 2007; Schulz-Schaeffer, 2010), widespread varicosities and dot-like structures containing $\mathrm{p}-\alpha$ Syn are commonly observed in mouse model and human DLB brains (Saito et al., 2003; Scott et al., 2010). This may represent axonal transport defects and presynaptic dysfunctions (Saito et al., 2003; Scott et al., 2010). Recent study showed that mutant $\alpha$ Syn (A53T) diminished levels of various motor proteins in neurons (Chung et al., 2009), supporting this scenario. Alternatively, excessive amounts of misfolded $\alpha$ Syn and $\mathrm{p}-\alpha$ Syn may aggregate at synapses, physically preventing the targeting of other presynaptic proteins (Kramer and SchulzSchaeffer, 2007). In experiments using Caenorhabditis elegans overexpressing the human $\alpha$ Syn, four genes related to the endocytosis process were identified as genetic modifiers for $\alpha$ Syn toxicity (Kuwahara et al., 2008). They included the two subunits of the adaptor protein (AP) complex 2, which interacts with clathrin and promotes presynaptic clathrin-mediated vesicle recycling (Morgan et al., 2000). Furthermore, proteomics analysis revealed that $\mathrm{p}$ - $\alpha$ Syn also preferentially interacted with the proteins involved in endocytosis, including clathrin heavy chain and subunit of AP-2 and AP-1 complexes, over the nonphosphorylated $\alpha$ Syn (McFarland et al., 2008). Clathrin-mediated recycling of exocytosed synaptic vesicles occurs in the periactive zone, a region adjacent to the active zone where synaptic vesicle is endocytosed (Haucke et al., 2011). Similarly, in Snap $25^{\text {S187A/S187A }}$ mice, immunoelectron microscopy showed preferential localization of $\alpha$ Syn at the periactive zone of the excitatory presynaptic nerve terminals (Fig. $3 D$ ). This might reflect the interaction of $\alpha$ Syn and p- $\alpha$ Syn with the proteins involved in clathrin-mediated endocytosis. Taking these findings together, presynaptic accumulation of $\alpha$ Syn and $\mathrm{p}-\alpha$ Syn could disturb the endocytosis process and consequently contribute to the development of VGLUT1-positive terminal enlargement.

Presynaptic accumulation of $\alpha$ Syn is considered an early event in the pathogenesis of $\alpha$-synucleinopathies (Neumann et al., 2002; Kramer and Schulz-Schaeffer, 2007; Schulz-Schaeffer, 2010). Mice overexpressing human $\alpha$ Syn showed presynaptic accumulation of $\alpha$ Syn and low DA release in the striatum. These findings were associated with abnormal distribution of SNARE proteins, which colocalized with $\alpha$ Syn aggregates. Similarly, accumulation of SNARE proteins and $\alpha$ Syn were reported in the striatum of PD patients (Garcia-Reitböck et al., 2010). These observations suggest that SNARE dysfunction likely occurs at an early stage of pathogenesis in nigrostriatal dysfunction observed in PD. By considering the findings observed in the VGLUT1positive nerve terminals, we expected that SNARE dysfunction might have induced presynaptic accumulation of $\alpha$ Syn, which consequently results in the development of neurodegenerative changes in the nigrostriatal system. However, contrary to our expectation, Snap $25^{\text {S187A/S187A }}$ mice showed no significant neurodegenerative changes in nigrostriatal dopaminergic neurons, suggesting that SNARE dysfunction alone was insufficient to cause nigrostriatal degeneration as observed in $\mathrm{PD}$, and appeared to be a downstream event associated with abnormal accumulation of $\alpha$ Syn.

In conclusion, the present study demonstrated that SNARE dysfunction leads to accumulation of endogenous $\alpha$ Syn in the corticostriatal nerve terminals. Presynaptic accumulation of $\alpha$ Syn is considered to be a key early event in the pathogenesis of $\alpha$-synucleinopathies. Although the "prion-like" propagation hypothesis of $\alpha$ Syn, including tau and TAR DNA-binding protein $43 \mathrm{kDa}$, is currently receiving considerable attention worldwide, our findings provide an insight to our understanding of the possible mechanisms that lead to presynaptic accumulation of endogenous $\alpha$ Syn. Moreover, given that SNAP-25 is reduced in the striatum of MSA brains (Tong et al., 2010), we speculate that a discontinuous pattern of $\alpha$ Syn pathologies usually found in MSA [i.e., glial cytoplasmic inclusions in the putaminal oligodendrocytes, and neuronal cytoplasmic inclusions and neuronal nuclear inclusions in the cortex (Yoshida, 2007; Ubhi et al., 2011)] might be potentially linked through the presynaptic accumulation of $\alpha$ Syn in the corticostriatal neurons. Further investigations on the Snap25 mutant mice with genetic ablation of $\alpha$ Syn would contribute to understanding the essential role of redistributed $\alpha$ Syn and should be a central issue in the following studies.

\section{References}

Asuni AA, Cunningham C, Vigneswaran P, Perry VH, O'Connor V (2008) Unaltered SNARE complex formation in an in vivo model of prion disease. Brain Res 1233:1-7. CrossRef Medline

Bamford NS, Robinson S, Palmiter RD, Joyce JA, Moore C, Meshul CK (2004) Dopamine modulates release from corticostriatal terminals. J Neurosci 24:9541-9552. CrossRef Medline

Burgoyne RD, Morgan A (2011) Chaperoning the SNAREs: a role in preventing neurodegeneration? Nat Cell Biol 13:8-9. CrossRef Medline

Burré J, Sharma M, Tsetsenis T, Buchman V, Etherton MR, Südhof TC (2010) Alpha-synuclein promotes SNARE-complex assembly in vivo and in vitro. Science 329:1663-1667. CrossRef Medline

Cabin DE, Shimazu K, Murphy D, Cole NB, Gottschalk W, McIlwain KL, Orrison B, Chen A, Ellis CE, Paylor R, Lu B, Nussbaum RL (2002) Synaptic vesicle depletion correlates with attenuated synaptic responses to prolonged repetitive stimulation in mice lacking $\alpha$-synuclein. J Neurosci 22:8797-8807. Medline

Chandra S, Gallardo G, Fernández-Chacón R, Schlüter OM, Südhof TC (2005) Alpha-synuclein cooperates with CSPalpha in preventing neurodegeneration. Cell 123:383-396. CrossRef Medline

Chung CY, Koprich JB, Siddiqi H, Isacson O (2009) Dynamic changes in presynaptic and axonal transport proteins combined with striatal neuroinflammation precede dopaminergic neuronal loss in a rat model of AAV $\alpha$-synucleinopathy. J Neurosci 29:3365-3373. CrossRef Medline

Chung YH, Joo KM, Kim MJ, Cha CI (2003) Immunohistochemical study on the distribution of alpha-synuclein in the central nervous system of transgenic mice expressing a human $\mathrm{Cu} / \mathrm{Zn}$ superoxide dismutase mutation. Neurosci Lett 342:151-154. CrossRef Medline

Darios F, Ruipérez V, López I, Villanueva J, Gutierrez LM, Davletov B (2010) Alpha-synuclein sequesters arachidonic acid to modulate SNAREmediated exocytosis. EMBO Rep 11:528-533. CrossRef Medline

Franklin KBJ, Paxinos G (2008) The mouse brain in stereotaxic coordinates, Ed 3. New York: Academic.

Fujiwara H, Hasegawa M, Dohmae N, Kawashima A, Masliah E, Goldberg MS, Shen J, Takio K, Iwatsubo T (2002) alpha-Synuclein is phosphorylated in synucleinopathy lesions. Nat Cell Biol 4:160-164. Medline

Furuya T, Hayakawa H, Yamada M, Yoshimi K, Hisahara S, Miura M, Mizuno Y, Mochizuki H (2004) Caspase-11 mediates inflammatory dopaminergic cell death in the 1-methyl-4-phenyl-1,2,3,6-tetrahydropyridine mouse model of Parkinson's disease. J Neurosci 24:1865-1872. CrossRef Medline 
Galvin JE, Lee VM, Trojanowski JQ (2001) Synucleinopathies: clinical and pathological implications. Arch Neurol 58:186-190. CrossRef Medline

Garcia-Reitböck P, Anichtchik O, Bellucci A, Iovino M, Ballini C, Fineberg E, Ghetti B, Della Corte L, Spano P, Tofaris GK, Goedert M, Spillantini MG (2010) SNARE protein redistribution and synaptic failure in a transgenic mouse model of Parkinson's disease. Brain 133:2032-2044. CrossRef Medline

Gerfen CR, Surmeier DJ (2011) Modulation of striatal projection systems by dopamine. Annu Rev Neurosci 34:441-466. CrossRef Medline

Gimbel DA, Nygaard HB, Coffey EE, Gunther EC, Laurén J, Gimbel ZA, Strittmatter SM (2010) Memory Impairment in transgenic Alzheimer mice requires cellular prion protein. J Neurosci 30:6367-6374. CrossRef Medline

Gureviciene I, Gurevicius K, Tanila H (2007) Role of alpha-synuclein in synaptic glutamate release. Neurobiol Dis 28:83-89. CrossRef Medline

Haucke V, Neher E, Sigrist SJ (2011) Protein scaffolds in the coupling of synaptic exocytosis and endocytosis. Nat Rev Neurosci 12:127-138. CrossRef Medline

Hayes NVL, Baines AJ (1996) Small synaptic vesicles. In: Biomembranes: a multi-volume treatise (Lee AG, ed), pp 75-122. Greenwich, CT: JAI.

Herzig MC, Kolly C, Persohn E, Theil D, Schweizer T, Hafner T, Stemmelen C, Troxler TJ, Schmid P, Danner S, Schnell CR, Mueller M, Kinzel B, Grevot A, Bolognani F, Stirn M, Kuhn RR, Kaupmann K, van der Putten PH, Rovelli G, et al. (2011) LRRK2 protein levels are determined by kinase function and are crucial for kidney and lung homeostasis in mice. Hum Mol Genet 20:4209-4223. CrossRef Medline

Hu K, Carroll J, Rickman C, Davletov B (2002) Action of Complexin on SNARE complex. J Biol Chem 277:41652-41656. CrossRef Medline

Iwai A, Masliah E, Yoshimoto M, Ge N, Flanagan L, de Silva HA, Kittel A, Saitoh T (1995) The precursor protein of non-A beta component of Alzheimer's disease amyloid is a presynaptic protein of the central nervous system. Neuron 14:467-475. CrossRef Medline

Iwasaki S, Kataoka M, Sekiguchi M, Shimazaki Y, Sato K, Takahashi M (2000) Two distinct mechanisms underlie the stimulation of neurotransmitter release by phorbol esters in clonal rat pheochromocytoma PC12 cells. J Biochem 128:407-414. CrossRef Medline

Kataoka M, Yamamori S, Suzuki E, Watanabe S, Sato T, Miyaoka H, Azuma S, Ikegami S, Kuwahara R, Suzuki-Migishima R, Nakahara Y, Nihonmatsu I, Inokuchi K, Katoh-Fukui Y, Yokoyama M, Takahashi M (2011) A single amino acid mutation in SNAP-25 induces anxiety-related behavior in mouse. PLoS One 6:e25158. CrossRef Medline

Kaushal N, Seminerio MJ, Shaikh J, Medina MA, Mesangeau C, Wilson LL, McCurdy CR, Matsumoto RR (2011) CM156, a high affinity sigma ligand, attenuates the stimulant and neurotoxic effects of methamphetamine in mice. Neuropharmacology 61:992-1000. CrossRef Medline

Kawamura Y, Fukaya M, Maejima T, Yoshida T, Miura E, Watanabe M, Ohno-Shosaku T, Kano M (2006) The $\mathrm{CB}_{1}$ cannabinoid receptor is the major cannabinoid receptor at excitatory presynaptic sites in the hippocampus and cerebellum. J Neurosci 26:2991-3001. CrossRef Medline

Kramer ML, Schulz-Schaeffer WJ (2007) Presynaptic $\alpha$-synuclein aggregates, not Lewy bodies, cause neurodegeneration in dementia with Lewy bodies. J Neurosci 27:1405-1410. CrossRef Medline

Kuwahara T, Koyama A, Koyama S, Yoshina S, Ren CH, Kato T, Mitani S, Iwatsubo T (2008) A systematic RNAi screen reveals involvement of endocytic pathway in neuronal dysfunction in alpha-synuclein transgenic $\mathrm{C}$. elegans. Hum Mol Genet 17:2997-3009. CrossRef Medline

Larsen KE, Schmitz Y, Troyer MD, Mosharov E, Dietrich P, Quazi AZ, Savalle M, Nemani V, Chaudhry FA, Edwards RH, Stefanis L, Sulzer D (2006) $\alpha$-Synuclein overexpression in PC12 and chromaffin cells impairs catecholamine release by interfering with a late step in exocytosis. J Neurosci 26:11915-11922. CrossRef Medline

Majewski H, Iannazzo L (1998) Protein kinase C: a physiological mediator of enhanced transmitter output. Prog Neurobiol 55:463-475. CrossRef Medline

Maroteaux L, Campanelli JT, Scheller RH (1988) Synuclein: a neuronspecific protein localized to the nucleus and presynaptic nerve terminal. J Neurosci 8:2804-2815. Medline

Masliah E, Rockenstein E, Veinbergs I, Sagara Y, Mallory M, Hashimoto M, Mucke L (2001) beta-amyloid peptides enhance alpha-synuclein accumulation and neuronal deficits in a transgenic mouse model linking Alz- heimer's disease and Parkinson's disease. Proc Natl Acad Sci U S A 98: 12245-12250. CrossRef Medline

McFarland MA, Ellis CE, Markey SP, Nussbaum RL (2008) Proteomics analysis identifies phosphorylation-dependent alpha-synuclein protein interactions. Mol Cell Proteomics 7:2123-2137. CrossRef Medline

Miyazaki T, Fukaya M, Shimizu H, Watanabe M (2003) Subtype switching of vesicular glutamate transporters at parallel fibre-Purkinje cell synapses in developing mouse cerebellum. Eur J Neurosci 17:2563-2572. CrossRef Medline

Morgan A, Burgoyne RD, Barclay JW, Craig TJ, Prescott GR, Ciufo LF, Evans GJ, Graham ME (2005) Regulation of exocytosis by protein kinase C. Biochem Soc Trans 33:1341-1344. CrossRef Medline

Morgan JR, Prasad K, Hao W, Augustine GJ, Lafer EM (2000) A conserved clathrin assembly motif essential for synaptic vesicle endocytosis. J Neurosci 20:8667-8676. Medline

Murphy DD, Rueter SM, Trojanowski JQ, Lee VM (2000) Synucleins are developmentally expressed, and $\alpha$-synuclein regulates the size of the presynaptic vesicular pool in primary hippocampal neurons. J Neurosci 20: 3214-3220. Medline

Nagy G, Matti U, Nehring RB, Binz T, Rettig J, Neher E, Sørensen JB (2002) Protein kinase C-dependent phosphorylation of synaptosome-associated protein of $25 \mathrm{kDa}$ at Ser 187 potentiates vesicle recruitment. J Neurosci 22:9278-9286. Medline

Nemani VM, Lu W, Berge V, Nakamura K, Onoa B, Lee MK, Chaudhry FA, Nicoll RA, Edwards RH (2010) Increased expression of alpha-synuclein reduces neurotransmitter release by inhibiting synaptic vesicle reclustering after endocytosis. Neuron 65:66-79. CrossRef Medline

Neumann M, Kahle PJ, Giasson BI, Ozmen L, Borroni E, Spooren W, Müller V, Odoy S, Fujiwara H, Hasegawa M, Iwatsubo T, Trojanowski JQ, Kretzschmar HA, Haass C (2002) Misfolded proteinase K-resistant hyperphosphorylated alpha-synuclein in aged transgenic mice with locomotor deterioration and in human alpha-synucleinopathies. J Clin Invest 110: 1429-1439. CrossRef Medline

Orimo S, Uchihara T, Nakamura A, Mori F, Kakita A, Wakabayashi K, Takahashi H (2008) Axonal alpha-synuclein aggregates herald centripetal degeneration of cardiac sympathetic nerve in Parkinson's disease. Brain 131:642-650. CrossRef Medline

Pan-Montojo F, Anichtchik O, Dening Y, Knels L, Pursche S, Jung R, Jackson S, Gille G, Spillantini MG, Reichmann H, Funk RH (2010) Progression of Parkinson's disease pathology is reproduced by intragastric administration of rotenone in mice. PLoS One 5:e8762. CrossRef Medline

Saito Y, Kawashima A, Ruberu NN, Fujiwara H, Koyama S, Sawabe M, Arai T, Nagura H, Yamanouchi H, Hasegawa M, Iwatsubo T, Murayama S (2003) Accumulation of phosphorylated alpha-synuclein in aging human brain. J Neuropathol Exp Neurol 62:644-654. Medline

Sakisaka T, Yamamoto Y, Mochida S, Nakamura M, Nishikawa K, Ishizaki H, Okamoto-Tanaka M, Miyoshi J, Fujiyoshi Y, Manabe T, Takai Y (2008) Dual inhibition of SNARE complex formation by tomosyn ensures controlled neurotransmitter release. J Cell Biol 183:323-337. CrossRef Medline

Schulz-Schaeffer WJ (2010) The synaptic pathology of alpha-synuclein aggregation in dementia with Lewy bodies, Parkinson's disease and Parkinson's disease dementia. Acta Neuropathol 120:131-143. CrossRef Medline

Scott DA, Tabarean I, Tang Y, Cartier A, Masliah E, Roy S (2010) A pathologic cascade leading to synaptic dysfunction in $\alpha$-synuclein-induced neurodegeneration. J Neurosci 30:8083-8095. CrossRef Medline

Sharma M, Burré J, Südhof TC (2011) CSPalpha promotes SNAREcomplex assembly by chaperoning SNAP-25 during synaptic activity. Nat Cell Biol 13:30-39. CrossRef Medline

Shimazaki Y, Nishiki T, Omori A, Sekiguchi M, Kamata Y, Kozaki S, Takahashi M (1996) Phosphorylation of 25-kDa synaptosome-associated protein. Possible involvement in protein kinase $\mathrm{C}$-mediated regulation of neurotransmitter release. J Biol Chem 271:14548-14553. CrossRef Medline

Shoji-Kasai Y, Itakura M, Kataoka M, Yamamori S, Takahashi M (2002) Protein kinase C-mediated translocation of secretory vesicles to plasma membrane and enhancement of neurotransmitter release from PC12 cells. Eur J Neurosci 15:1390-1394. CrossRef Medline

Spillantini MG, Goedert M (2000) The alpha-synucleinopathies: Parkinson's disease, dementia with Lewy bodies, and multiple system atrophy. Ann N Y Acad Sci 920:16-27. Medline 
Südhof TC (2004) The synaptic vesicle cycle. Annu Rev Neurosci 27:509547. CrossRef Medline

Tabuchi K, Blundell J, Etherton MR, Hammer RE, Liu X, Powell CM, Südhof TC (2007) A Neuroligin-3 mutation implicated in autism increases inhibitory synaptic transmission in mice. Science 318:71-76. CrossRef Medline

Tapia-González S, Giráldez-Pérez RM, Cuartero MI, Casarejos MJ, Mena MÁ, Wang XF, Sánchez-Capelo A (2011) Dopamine and alphasynuclein dysfunction in Smad3 null mice. Mol Neurodegener 6:72. CrossRef Medline

Tong J, Wong H, Guttman M, Ang LC, Forno LS, Shimadzu M, Rajput AH, Muenter MD, Kish SJ, Hornykiewicz O, Furukawa Y (2010) Brain alpha-synuclein accumulation in multiple system atrophy, Parkinson's disease and progressive supranuclear palsy: a comparative investigation. Brain 133:172-188. CrossRef Medline

Ubhi K, Low P, Masliah E (2011) Multiple system atrophy: a clinical and neuropathological perspective. Trends Neurosci 34:581-590. CrossRef Medline
Wickens JR, Arbuthnott GW (2005) Structural and functional interactions in the striatum at the receptor level. In: Dopamine, Handbook of Chemical Neuroanatomy, Vol 21 (Dunnett SB, Bentivoglio M, Björklund A, Hökfelt T, eds), pp 199-236. Amsterdam: Elsevier.

Yamamori S, Itakura M, Sugaya D, Katsumata O, Sakagami H, Takahashi M (2011) Differential expression of SNAP-25 family proteins in the mouse brain. J Comp Neurol 519:916-932. CrossRef Medline

Yasuda T, Hayakawa H, Nihira T, Ren YR, Nakata Y, Nagai M, Hattori N, Miyake K, Takada M, Shimada T, Mizuno Y, Mochizuki H (2011) Parkin-mediated protection of dopaminergic neurons in a chronic MPTP-minipump mouse model of Parkinson disease. J Neuropathol Exp Neurol 70:686-697. CrossRef Medline

Yasuda T, Nakata Y, Mochizuki H (2012) $\alpha$-Synuclein and neuronal cell death. Mol Neurobiol. Advance online publication. Retrieved November 8, 2012. doi:10.1007/s12035-012-8327-0. CrossRef

Yoshida M (2007) Multiple system atrophy: $\alpha$-synuclein and neuronal degeneration. Neuropathology 27:484-493. CrossRef Medline 